\title{
EVALUASI PROSEDUR KEGIATAN EKSPOR PADA PT BINTANG ASIA USAHA
}

\author{
Rodiatul Muthmainah 1), Doni Putra Utama ${ }^{2)}$ \\ Politeknik Negeri Batam \\ Jurusan Manajemen Bisnis, Program Studi Akuntansi \\ Jl Ahmad Yani, Batam Centre, Batam 29461, Indonesia \\ E-mail: rodiatul.muthmainah@gmail.com ${ }^{1)}$ \\ doni@polibatam.ac.id ${ }^{2)}$
}

\begin{abstract}
Abstrak
Penelitian ini dilakukan di PT Bintang Asia Usaha dan membahas mengenai evaluasi prosedur kegiatan ekspor pada PT Bintang Asia Usaha. Adanya kesalahan pada saat pembuatan invoice dan packing list yaitu, pada saat penginputan gross weight dan net weight yang tertukar dan adanya keterlambatan dalam pengiriman dokumen pengapalan. Objek penelitian ini adalah peosdur dan dokumen terkait kegiatan ekspor perusahaan. Metode yang digunakan dalam penelitian ini adalah metode analisis deskriptif yang mengambarkan prosedur dan dokumen ekspor pada PT Bintang Asia Usaha. Hasil penelitian yaitu terdapat kesalahan pada saat pembuatan invoice dan packing list serta terjadinya keterlambatan dalam pengiriman dokumen pengapalan yang disebabkan karena kurangnya sumber daya manusia (SDM) yang ada di perusahaan. Penulis memberikn solusi sebaiknya adanya penambahan karyawan pada bagian ekspor supaya tidak hanya satu orang saja yang mengurus dan menangani semua kegiatan yang berhubungan dengan ekspor. Tujuan dari penelitian ini adalah untuk mengetahui kendala apa saja yang sering terjadi pada saat melakukan kegiatan ekspor.
\end{abstract}

Kata kunci: Evaluasi, prosedur, ekspor

\begin{abstract}
This research was conducted at PT Bintang Asia Usaha and discussed the evaluation of procedures for export activities at PT Bintang Asia Usaha. There was an error when making the invoice and packing list, that is, when the gross weight and net weight input was exchanged. The object of the research is procedure and document export the companys. The method used in this study is a descriptive analysis method that describes export procedures and documents at PT Bintang Asia Usaha. The results of the study were there were errors when making invoices and packing lists as well as the delay in sending shipping documents due to lack of human resources in the company. The author gives the solution that there should be additional employees in the export department so that not only one person takes care and handles all activities related to exports. The purpose of this study is to find out what obstacles often occur while doing export activities.
\end{abstract}

Keywords: Evaluatuion, Procedur, export 


\section{PENDAHULUAN}

Pada mulanya hubungan perdagangan hanya terbatas pada satu wilayah Negara saja, tetapi dengan adanya perkembangan zaman dan arus perdagangan maka hubungan perdagangan tersebut tidak hanya terbatas pada wilayah Negara tertentu saja, tetapi juga dengan para pedagang di berbagai Negara. Selain itu perdagangan luar Negeri adalah salah satu aspek penting dalam perekonomian di setiap Negara dan kegiatan ekspor impor merupakan faktor penentu dalam menentukan roda perekonomian terutama di Indonesia.

Potensi alam dari masing-masing Negara yang berbeda mendorong keinginan Negara lain untuk mendapatkan sesuatu yang tidak bisa didapat di Negara nya. Faktor ekonomi juga menjadi faktor terjadinya perdagangan internasional, yakni ketika suatu pihak berusaha mendapatkan keuntungan lebih dari usaha yang dikelolanya. Hal ini secara otomatis memaksa kebutuhan untuk memenuhinya dengan cara melakukan perdagangan antar Negara (Susilo, 2013).

Pengetahuan mengenai prosedur ekspor impor Indonesia atau tata cara pelakasanaan perdagangan bebas internasional maupun berbagai peraturan yang terdapat dalam Undang-Undang Nomor 17 Tahun 2006 tentang perubahan undang-undang No.10 Tahun 1995 tentang kepabeanan (Purwinto M, 2008). Pada saat akan melakukan kegiatan ekspor impor pasti berhubungan dengan proses kepabaeanan, prosedur ekspor serta dokumen-dokumen penting yang terdapat dalam transaksi ekspor. Dalam melakukan kegiatan ekspor ada beberapa dokumen yang harus dilengkapi seperti Pemberitahuan Ekspor Barang (PEB), Bill of Lading (B/L, Airway Bill / AWB atau dokumen transpor lainnya seperti postel receipt, cargo receipt, Invoice, Packing List, Surat Keterangan Asal (SKA), Asuransi (jika diminta oleh pembeli) (Susilo, 2013).

PT Bintang Asia Usaha merupakan perusahaan manufaktur yang bergerak di bidang Metal Stamping. Perusahaan tersebut memproduksi lingkaran stainless steel dengan kualitas yang baik, produk yang dihasilkan akan dijual atau dipasarkan di India oleh sebab itu perusahaan memasarkan produk nya melalui kegiatan ekspor impor. Sebelum melakukan kegiatan ekspor perusahaan harus mempersiapkan dan melengkapi semua dokumen yang diperlukan. Untuk mempermudah mengurus kelengkapan dokumen ekspor PT Bintang Asia Usaha menggunakan jasa Pengusaha Pengurus Jasa Kepabeanan (PPJK).

Dalam melakukan kegiatan ekspor terkadang terdapat masalah yaitu adanya kesalahan pada saat pembuatan invoice dan packing list, yaitu terdapat perbedaan jumlah gross weight yang ada di invoice dan packing list sehingga dapat menimbukan revisi, serta adanya keterlambatan dalam pengiriman dokumen pengapalan dan adanya kerusakan pada alat pendukung seperti timbangan rusak yang dapat mengakibatkan keterlambatan dalam pengiriman barang. Berdasarkan latar belakang yang diuraikan di atas, maka penulis tertarik untuk melakukan penelitian dengan judul "EVALUASI PROSEDUR KEGIATAN EKSPOR PADA PT BINTANG ASIA USAHA"

Berdasarkan latar belakang masalah, maka penulis mengidentifikasi masalah sebagai berikut: a) adanya kesalahan pada saat pembuatan invoice dan packing lst. b) terdapat keterlambatan dalam pengiriman dokumen pengapalan dan adanya kerusakan pada alat pendukung seperti timbangan.

\section{KAJIAN PUSTAKA}

Menurut Peraturan Menteri Keuangan Nomor 145/PMK.04/2007 tentang ketentuan kepabeanan di bidang ekspor sebagaimana telah diubah dengan Peraturan Menteri Keuangan Nomor 1458/PMK.04/2011 adalah sebgai berikut:

a. Ekspor adalah kegiatan mengeluarkan barang dari daerah pabean

b. Barang ekspor merupakan barang yang dikeluarkan dari daerah pabean 
Rodiatul Muthmainah \& Doni Putra Utama, Evaluasi Prosedur Kegiatan Ekspor...

c. Eksportir adalah orang atau badan hukum yang melakukan kegiatan mengeluarkan barang dari daerah pabean

d. Bea keluar adalah pungutan Negara berdasarkan undang-undang Kepabeanan yang dikenakan terhadap barang ekspor

e. Pemberitahuan pabean ekspor (PEB) adalah pernyataan yang dibuat oleh seseorang untuk melaksanakan kewajiban pabean di bidang ekspor secara tertulis pada formulir atau data elektronik.

Ekspor dapat diartikan sebagai pengangkutan barang dalam jumlah tertentu dari suatu Negara ke Negara lain baik untuk di perdagangkan maupun tidak untuk di perdagangkan, dengan memenuhi kewajiban kepabeanan yang telah ditentukan (Purwinto M, 2008).

Menurut (M.S 2008) pihak atau pelaku yang berperan dalam pelaksanaan ekspor adalah sebagai berikut:

a. Eksportir

Eksportir adalah pihak yang menjual barang ke importer (buyer) di luar Negeri.

b. Bank

Peranan bank dalam kegiatan ekspor dan impor antara lain:

1. sebagai penyedia kredit ekspor jika diperlukan oleh eksportir

2. memperlancar dan mengamankan transaksi melalui letter of credit (L/C). letter of credit adalah sebuah dokumen yang dikeluarkan oleh bank yang menjamin kemampuan nasabah untuk membayar barang atau jasa.

c. Departemen Perdagangan dan

Perindustrian

Peran departemen perdagangan dan perindustrian dalam kegiatan ekspor impor antara lain:

1. Sebagai instansi pemerintah yang mengeluarkan izin sebagai Eksportir Terdaftar (ET) dan izin sebagai Importir.

2. Mengeluarkan dokumen ekspor yang disebut "Certificate of origin" atau "surat Keterangan Asal" yang merupakan surat pernyataan bahwa barang yang di ekspor adalah barang yang dibuat di Negara Indonesia.

3. Mengawasi, mengatur dan memonitor barang-barang yang terkena kuota.

d. Surveyor Independent

Surveyor independent mempunyai peran sebagai wakil dalam pemriksaan barang-barang yang akan dimuat kedalam container di lokasi eksportir, dalam hal ini pemeriksaan akan dilakukan jka ada permintaan dari pihak importir.

e. Shipping Company

Peranan shipping company dalam kegiatan ekspor yaitu:

1. Sebagai perusahaan jasa pengapalan barang-barang yang di ekspor atau di impor dan juga sebagai penyedia container kosong bagi eksportir.

2. Mengeluarkan dokumen pengapalan yang disebut "Bill of Lading $(B / L)$ " yang merupakan dokumen dalam pencairan L/C di bank.

f. Ekspedisi Muatan Kapal laut (EMKL) atau Pengusaha Pengurus Jasa Kepabeanan (PPJK)

Ekspedisi Muatan Kapal Laut (EMKL) merupakan pengangkut barang (kargo) yang bertujuan untuk mengangkut barang dari tempat eksportir ke pelabuhan laut atau sebaliknya, sedangkan Pengusaha Pengurus Jasa Kepabeanan (PPJK) merupakan perusahaan jasa yang bertindak untuk mengurus formalitas kepabeanan dan hal-hal yang terkait di dalamnya.

g. Bea dan Cukai

Peranan Bea dan Cukai sebagai instansi pemerintah dalam kegiatan eskpor impor adalah sebagai berikut:

1. Mengawasi barang-barang yang dieskpor atau diimpor, khususnya yang kena pajak ekspor (PE)

2. Mengawasi yang terkait dengan fasilitas Bapeksta (Badan Pengeskpor Swasta) 


\section{h. Perusahaan Asuransi}

Peranan perusahaan asuransi adalah sebagai jasa penyedia asuransi untuk kegiatan ekspor dan impor.

Prosedur adalah suatu urutan klerikal, biasanya melibatkan beberapa orang dalam suatu departemen atau lebih, yang dibuat untuk menjamin penanganan seragam transaksi perusahaan yang terjadi berulangulang (Mulyadi, 2016).

Prosedur ekspor adalah rangkaian langkah demi langkah yang harus diambil oleh seorang eksportir mulai dari mempersiapkan barang dagangannya sampai barang dimuat ke atas kapal di pelabuhan muat, sesuai dengan peraturan pemerintah yang berlaku dan kebiasaan dalam perdagangan internasional (M.S., 2008).

Prosedur kepabeanan ekspor adalah sebagai berikut

(http://www.beacukai.go.id/arsip/pab/ekspo r.html):

a. Eksportir wajib memberitahukan barang yang akan diekspor ke kantor Bea dan cukai tempat pemuatan dengan menggunakan Pemberitahuan Ekspor Barang (PEB)

b. PEB dibuat oleh eksportir berdasarkan dokumen pelengkap pabean berupa:

\section{Invoice}

2. Packing list

3. Dokumen lain yang diwajibkan

c. Eksportir wajib memenuhi ketentuan larangan dan/atau pembatasan ekspor yang ditetapkan oleh instansi teknis

d. Penghitungan besaran Bea keluar dilakukan sendiri oleh Eksportir secara Self Assessment

e. Pemberitahuan Ekspor Barang (PEB) disampaikan ke kantor Bea dan Cukai pemuatan paling cepat 7 (tujuh) hari sebelum tanggal perkiraan ekspor dan paling lambat sebelum barang eskpor masuk ke kawasan pabean tempat pemuatan

f. Atas Ekspor barang curah, eksportir atau PPJK dapat menyampaikan PEB sebelum kebrangkatan sarana pengangkut g. Pengurusan PEB dapat dilakukan sendiri oleh eksportir atau dikuasakan kepada Pengusaha Pengurus Jasa kepabeanan (PPJK)

h. Kantor pabean yang sudah menerapkan sistem PDE (pertukaran data elektronik) kepabeanan, eksportir / PPJK harus menyerahkan PEB dengan menggunakan sistem PDE kepabeanan. Pengecualian

kewajibamemberitahukan PEB

a. Barang pribadi penumpang

b. Barang awak sarana pengangkut

c. Barang pelintas batas, atau

d. Barang kiriman melalui pos dengan ketentuan berat tidak melebihi 100 (seratus) kilogram.

Setiap orang yang tidak melaporkan pembatalan ekspor sebagaimana dimaksud dalam pasal 14 ayat (2), dikenakan sanksi administrasi berupa denda Rp. 5.000.000,00 (lima juta rupiah). setiap orang yang salah memberikan jenis dan / atau jumlah barang dalam pemberitahuan pabean ekspor yang mengakibatkan tidak terpenuhinya pungutan negara dibidang ekspor akan dikenakan sanksi administrasi dalam bentuk denda minimal $100 \%$ (seratus persen) dari pungutan Negara dibidang ekspor yang kurang dibayar dan paling banyak $1.000 \%$ (seribu persen) dari pungutan Negara di bidang ekspor yang kurang dibayar (Purwinto M, 2008). Setiap orang yang:

a. Mengekspor barang tanpa m pemberitahuan pabean

b. Dengan sengaja memberitahukan jenis dan/atau jumlah barang dalam pemberitahuan pabean secara salah yang mengakibatkan tidak terpenuhinya Negara di bidang ekspor

c. Memuat barang ekspor di luar kawasan pabean tanpa izin kepala kantor pabean

d. Membongkar barang ekspor di dalam derah pabean tanpa izin kepala kantor pabean, dipidana penjara paling sedikit 1 (satu) tahun dan dipidana penjara paling lama 10 (sepuluh) tahun dan denda paling sedikit Rp 50.000.000 (lima puluh juta) dan denda paling 
Rodiatul Muthmainah \& Doni Putra Utama, Evaluasi Prosedur Kegiatan Ekspor...

banyak Rp 5.000.000.000,00 (lima miliyar rupiah). (Purwinto M, 2008).

Menurut (Susilo,2013) dokumen yang harus dipersiapkan pada saat melakukan kegiatan ekspor adalah sebagai berikut:

a. Shiping instruction ( $S / I)$

Shipping instruction merupakan perintah instruksi pengapalan pengiriman yang dibuat oleh eksportir kepada perusahaan pengangkutan.

Perusahaan pengangkutan disini bisa berupa perusahaan pelayaran untuk laut perusahaan penerbangan untuk udara maupun darat atau lainnya jika memang pengiriman atau ekspor barang tidak melalui laut atau udara atau darat sekalipun. Shipping Intruction merupakan dokumen yang berisi perintah kerja kepada pihak pengangkutan untuk mengangkut barang ekspor milik eksportir, hal-hal yang harus dilengkapi dalam dokumen SI adalah:

1. Tanggal dan nomer Shiping instruction (SI)

2. Nama perusahaan pengangkut yang ditunjuk (pelayaran atau penerbangan)

3. Nama eksportir (pengirim barang)

4. Nama importir (penerima barang)

5. Nama komiditasi yang diekspor

6. Jumlah dan jenis pengemas (jika menggunakan container, maka sebutkan jumlah container, ukuran yang diminta dan nomor container)

7. Gross weight (berat kotor)

8. Net weight (berat bersih)

9. Pelabuhan muat

10. Pelabuhan bongkar

11. Rencana tanggal ekspor

12. Tanggal stuffing (muat barang) dan lokasinya

13. Metode pembayaran ongkos pengangkutan (dimuka atau di kemudian setalah barang sampai)

\section{b. Commercial Invoice}

Commercial invoice merupakan dokumen atau surat tagihan uang yang diterbitkan oleh eksportir yang ditunjukan kepada importir.
Commercial invoice berisikan nilai barang per item dan total nilai barang

c. Packing List

Packing list adalah dokumen pengemasan yang menunjukkan jumlah jenis serta berat dari barang yang akan di ekspor dan merupakan penjelasan dari uraian barang yang disebut di dalam nomer commercial invoice. Hal-hal yang harus dicantumkan didalam packing list:

1. Nama eksportir

2. Consingnee atau buyer (importir)

3. Nomor packing list dan tanggal

4. Quantity atau jumlah barang

5. Nama barang

6. Gross weight (berat kotor)

7. Net weight (berat bersih)

8. Vessel name (nama kapal)

9. ETD (Estimated Date Departure), tanggal keberangkatan kapal

10. Notify party (pihak ketiga setelah consignee)

11. Nomor L/C (Leter of Credit) jika ada

d. Pemberitahuan Ekspor Barang

Eksportir wajib memberi tahu barang yang akan diekspor ke kantor pabean. Pengelolaan PEB di kantor pabean dapat dilakukan oleh eksportir atau kepada Perusahaan Pengurusan Jasa Kepabeanan (PPJK), yaitu badan usaha yang melakukan kegiatan bea cukai untuk dan dengan wewenang importir atau eksportir.

PEB dibuat oleh eksportir berdasarkan dokumen-dokumen berikut:

1. Packing List

2. Invoice

3. Dan dokumen yang diwajibkan untuk memenuhi ketentuan umum dibidang ekspor

4. Surat Tanda Bukti Setor (STBS) dalam hal barang ekspor yang terkena bea keluar.

\section{e. Bill of Lading $(\mathrm{B} / \mathrm{L})$}

Bill of lading adalah surat atau dokumen yang diterbitkan oleh shipping line atau freight forwarder untuk setiap pengiriman barang ekspor. Bill of lading biasanya 
diterbitkan pada tanggal keberangkatan kapal, bill of lading berfungsi sebagai bukti untuk mengambil barang di tujuan dan juga sebagai lampiran dalam proses pembutan $\mathrm{COO}$ (Certificate of Origin)

Macam-macam Bill of lading (Susilo, 2013):

1. Ocean Bill of lading (Marine Bill of Lading)

Bill of Lading yang dikeluarkan oleh perusahaan pelayaran kepada pengiriman barang untuk ditunjukan kepada penerima barang di pelabuhan tujuan.

2. Master Bill of Lading

Bill of lading yang dikeluarkan oleh perusahaan pelayaran kepada freight forwarding yang bertindak sbagai shipper untuk dipisahkan oleh perusahaan pelayaran atau dinamakan juga sebagai surrender bill of lading.

3. Memo Bill of lading

Bill of lading yang dikeluarkan oleh perusahaan pelayaran feeder kepada agen-agen perusahaan pelayaran yang telah mem-booking space di atas kapal feeder untuk diangkut ke pelabuhan transit

4. Second/Trough/Transit Bill of lading

Bill of Lading yang dikeluarkan oleh pihak perusahaan pelayaran yang berada di pelabuhan transit yang mana telah terjadi perpindahan muatan dari kapal pengangkut pertama ke kapal pengangkut kedua.

5. Sea way Bill of Lading

Bill of Lading yang dikeluarkan oleh pihak perusahaan pelayaran kepada shipper maupun freight forwading yang mana pihak penerima barang di pelabuhan tujuan dapat mengambil barang tanpa harus menunjukan dokumen asli kepada pihak agen perusahaan yang dimaksud di pelabuhan tujuan.

6. Freight Bill of lading

Bill of lading yang dikeluarkan oleh pihak perusahaan pelayaran untuk kepentingan perhitungan pembayaran freight forwarding serta biaya-biaya yang harus dibayar oleh shipper maupun consignee.

7. House Bill of Lading

Bill of Lading yang dikeluarkan oleh freight forwarding untuk ditunjukan kepada shipper sebagai kelanjutan dari master bill of lading. House Bill of Lading dapat juga disebut through bill of lading

8. Switch Bill of Lading

Bill of Lading yang dikeluarkan oleh agen pelayaran yang berada di Negara ketiga atas permintaan shipper untuk diterbitkan bill of lading yang baru untuk mengadakan perubahan atas nama shipper, consignee, maupun notify party yang tertera pada bill of lading.

f. Air way Bill (AwB)

Air way Bill adalah dokumen yang dibuat atas perjanjian antara shipper atau cargo agent dengan airlines yang merupakan bukti kontrak kerjasama untuk pengangkutan barang melalui udara atau melalui rute yang dilewati airlines tersebut.

g. Certificate of Origin (COO)

Certificate of origin atau yang biasa dikenal dengan surat keterangan asal merupakan dokumen yang dibuat oleh eksportir dan disertakan pada saat mengirim atau mengekspor barang ke suatu Negara tertentu. di mana negara penerima barang telah menyetujui perjanjian untuk menyediakan fasilitas barang dari negara asal untuk memasuki negara tujuan.

Persyaratan untuk mendapatkan surat keterangan asal:

1. Berdasarkan surat keputusan Menteri Perindustrian dan Perdagangan No. 130/MPP/Kep-/6/6/1996 ditetapkan bahwa bagi kalangan dunia usaha khususnya eksportir yang akan mengekspor barang nya ditetapkan bahwa persyaratan memperoleh Surat Keterangan Negara Asal (SKA) Barang Ekspor Indonesia sebagai berikut :

- Membuat surat permohonan SKA

- PEB (Pemberitahuan Barang Ekspor) 
Rodiatul Muthmainah \& Doni Putra Utama, Evaluasi Prosedur Kegiatan Ekspor...

- AWB (Air Way Bill) atau B/L (Bill of Lading)

- Mengisi formulir SKA (Blanko formulir dapat diperoleh di kanwil DEPERDAG ATAU Dinas Perindang Dati I setempat dengan cara mengajukan surat permohonan beserta potocopyan PEB yang bersangkutan)

2. Persyaratan Khusus

- Bagi SKA Prefensial: harus memenuhi ketentuan "rule of origin" sesuai dengan ketentuan yang ditetapkan oleh negera importer (pemohon menyertakan "cost calculation" dan atau "production structure" sesuai dengan ketentuan yang berlaku pada jenis barag yang akan di ekspor)

- Bagi SKA untuk barang terkena kuota: didukung dengan kuota sesuai dengan barang yang di ekspor.

Proses penerbitan SKA paling lambat satu hari keja terhitung dari tanggal diterimanya permohonan SKA. Bagi SKA yang tidak memenuhi syarat harus diberitahukan kepada pemohon paling lambat satu hari kerja terhitung dari tanggal diterimanya permohonan.

\section{HASIL DAN PEMBAHASAN}

\section{Data dan Dokumen yang Diolah/ Dihasilkan}

Data yang diolah invoice, packing list, bill of lading.

Data yang dihasilkan:

a. Stiker barang ekspor

b. Master Packing List (MPL)

c. Master Invoice Summary (MIS)

d. Surat Keterangan Asal (SKA)

\section{Adanya kesalahan pada saat pembuatan invoice dan packing list}

Commercial invoice adalah dokumen atau surat tagihan uang yang diterbitkan oleh eksportir yang ditunjukan kepada importir. Commercial invoice berisikan daftar rincian barang detail yang berisikan nama Shipper, Consignee, Notify Party, Nama Vessel \& Voyage, Nilai Invoice per Item barang maupun total keseluruhan, Jumlah barang. Packing list adalah dokumen packing yang menunjukkan jumlah jenis serta berat dari barang yang akan di ekspor dan merupakan penjelasan dari deskripsi barang yang dimaksud dalam nomer commercial invoice. Invoice dan packing list dibuat oleh perusahaan yang melakukan pengemasan barang secara langsung.

Kesalahan yang tejadi pada saat pembuatan invoice dan packing list yaitu pada saat penginputan gross weight dan net weight yang menyebabkan berat yang di packing list dan invoice tidak sesuai dengan berat barang sesungguhnya, serta adanya kesalahan pencatatan nomor conteiner yang mengakibatkan barang tidak bisa keluar dari pelabuhan, karena nomor container yang ada di packing list tidak sesuai dengan nomor container yang telah dipesan, dan adanya penambahan grade yang diminta oleh customer secara tiba-tiba sehingga adanya perubahan yang terdapat di invoice dan berpengaruh pada saat pembuatan surat keterangan Asal (SKA). Hal ini disebabkan karena kurang nya sumber daya manusia yang ada di perusahaan yang bisa menghambat proses kegiatan ekspor, karena karyawan yang terdapat dibagian ekspor hanya satu jadi semua pekerjaan dari mulai mengirim daftar barang ke customer membuat invoice dan packing list, memesan container sampai mengirim dokumen ke customer dilakukan hanya oleh satu orang saja.

Jika terdapat kesalahan pada saat pembuatan invoice dan packing list kemungkinan barang tidak dibisa dikirim dan tidak sampai ketempat tujuan, eksportir tidak akan mendapat pelunasan atas barang yang telah dikirim. Sebelum membuat invoice dan packing list pastikan eksportir sudah benar-benar memastikan kepada customer bahwa invoice yang dibuat sudah sesuai dengan sales order, dan melakukan pengecekan ulang untuk memastikan data yang dimasukan di invoice dan packing list sudah benar. 
Invoice dan packing list merupakan dokumen penting pada saat melakukan kegiatan ekspor, hal ini disebabkan karena:

a. Sebagai data pendukung dan jaminan atas barang yang akan di ekspor

b. Sebagai dokumen untuk menerbitkan Bill Of Lading (B/L), Surat Keterangan Asal (SKA), dan Pemberitahuan Ekspor Barang (PEB)

c. Sebagai perbandingan bagi importir terhadap barang apa saja yang di pesan dan barang apa saja yang dikirim oleh eksportir

\section{Keterlambatan Pengiriman Dokumen Pengapalan dan Adanya kerusakan pada Alat Pendukung}

Dokumen Pengapalan adalah dokumen pendukung wesel dalam dan luar negeri dalam transaksi domestik, dokumen pengapalan minimum memuat $\mathrm{B} / \mathrm{L}$ dan invoice penjualan dan packing list, sedangkan dalam transaksi luar negeri dokumen minimum memuat $\mathrm{B} / \mathrm{L}$ kelautan, sertifikat asuransi pelayaran dan faktur penjualan. selain itu, dokumen tersebut juga dilampiri dengan dokumen yang diperjanjikan antara pembeli dan penjual serta dokumen lain yang dipersyaratkan negara tujuan, seperti Surat Keterangan Asal (SKA), sertifikat analisis, sertifikat pemeriksaan dan berat muatan, sertifikat keaslian barang.

Bagian yang terpenting dalam dokumen pengapalan adalah bill of lading (B/L) atau Konosemen, karena di dalam B/L terdapat dua kepentingan yaitu kepentingan perniagaan dan kepentingan pengangkutan barang yang terdapat di dalam bill of lading (B/L). Menurut pasal 506 KUHD-RI konosemen adalah suatu surat yang diberi tanggal dan ditanda tangani, yang menandakan bahwa pengangkut sudah menerima barang dengan maksud untuk diangkut ke tempat tujuan yang ditunjuk, juga dengan perjanjian bagaimana penyerahan akan dilakukan.

Keterlambatan terjadi karena kurangnya persiapan dari bagian eskpor dikarenakan banyak nya permintaan barang yang masuk dan Kurangnya jumlah karyawan yang terdapat dibagian tersebut sehingga proses pengiriman barang mengalami keterlambatan. Dokumen pengapalan berfungsi untuk mengambil barang pesanan dari shipping agent dan bea cukai setempat, serta berfungsi untuk pencairan Letter of Credit (L/C), dan sabagai bukti hak milik barang yang diangkut oleh kapal.

Alat pendukung merupakan alat yang digunaka oleh perusahaan untuk mempersiapakan barang yang telah selesai dibuat untuk dikemas, sebelum melakukan pengemasan perusahaan biasanya mengukur atau menimbang circle sesuai dengan ukurannya. Pada saat melakukan penimbangan biasanya melebihi kapasitas sehingga menybabkan terjadinya kerusakan pada timbangan, hal ini dapat memperlambat pengemasan.

\section{Prosedur Kegiatan Ekspor}

Berikut prosedur Kepabeanan kegiatan ekspor berdasarkan peraturan Direktorat Jendral Bea dan Cukai:

a. Eksportir/ Kuasanya menyampaikan dokumen Pemberitahuan Ekspor Barang (PEB) ke Kantor Bea Cukai tempat pemuatan.

b. Terhadap Barang Ekspor yang diberitahukan dalam PEB dilakukan penelitian dokumen setelah dokumen pemberitahuan disampaikan.

c. Jika terhadap penelitian dokumen PEB menunjukkan pengisian atas data PEB tidak lengkap dan/atau tidak sesuai, diterbitkan respon Nota Pemberitahuan Penolakan (NPP).

d. Jika dalam penelitian larangan dan/atau pembatasan menunjukkan dokumen persyaratan belum dipenuhi maka diterbitkan Nota Pemberitahuan Persyaratan Dokumen (NPPD).

e. Dalam hal hasil penelitian Sistem Komputer Pelayanan menunjukan lengkap dan sesuai, dan tidak termasuk barang yang dilarang atau dibatasi ekspornya, atau termasuk barang yang dilarang atau dibatasi ekspornya tetapi 
Rodiatul Muthmainah \& Doni Putra Utama, Evaluasi Prosedur Kegiatan Ekspor...

persyaratan ekspornya telah dipenuhi, serta barang tidak dilakukan pemeriksaan fisik, PEB diberi nomor dan tanggal pendaftaran dan diterbitkan respon NPE.

f. Dalam hal dilakukan pemeriksaan fisik, maka diterbitkan Pemberitahuan Pemeriksaan Barang (PPB). Jika pemeriksaan fisik barang ekspor menunjukkan:

1. Hasil sesuai, maka diterbitkan Nota Pelayanan Ekspor (NPE).

2. Hasil tidak sesuai, diteruskan kepada Unit Pengawasan untuk penelitian lebih lanjut.

\section{Solusi}

Berdasarkan penelitian yang dilakukan terkait evaluasi kegiatan ekspor, maka penulis menyarankan solusi sebgaia berikut:

a. Kesalahan pada saat pembuatan Invoice dan Packing List, penulis menyarankan sebaiknya dilakukan pengecekan setiap selesai pembuatan invoice dan packing list dan pastikan ke customer bahwa invoice dan packing list yang sudah dibuat sudah bener-benar sesuai dengan Sales Contrat.

b. Sebaiknya dilakukan penambanhan karyawan atau sumber daya manusia (SDM) di perusahaan khususnya dibagian eskpor, supaya semua keperluan atau persiapan ekspor tidak hanya di lakukan oleh satu orang saja, karena jika semuanya dilakukan oleh satu orang maka kegiatan ekspor yang ada diperusahaan menjadi kurang efektif.

\section{KESIMPULAN DAN SARAN \\ Kesimpulan}

Berdasarkan pembahasan pada bab IV, maka diperoleh kesimpulan sebagai berikut:

a) Invoice dan packing list merupakan dokumen penting dalam melakukan kegiatan ekspor, karena berfungsi sebagai data pendukung dan jaminan atas barang yang akan di eksopr, yaitu sebagai dokumen yang digunakan untuk menerbitkan bill of lading $(\mathrm{B} / \mathrm{L})$, Surat
Keterangan Asal (SKA) dan Pemberitahuan Ekspor Barang (PEB).

b) Dokumen pengapalan terdiri dari invoice, packing list, bill of lading (B/L), asuransi, dan Surat Keterangan Asal (SKA). Bill of lading $(\mathrm{B} / \mathrm{L})$ merupakan bagian yang terpenting dalam dokumen pengapalan karena terdapat dua kepentingan yaitu kepentingan perniagaan dan kepentingan pengangkutan barang yang terdapat di dalam bill of lading (B/L). Dokumen pengapalan berfungsi untuk mengambil barang pesanan dari shipping agent dan bea cukai setempat, serta berfungsi untuk pencairan letter of credit (L/C), dan sebagai bukti hak milik barang yang diangkut oleh kapal.

c) PT Bintang Asia Usaha merupakan perusahaan yang baru berdiri pada tahun 2017 sehingga perusahaan tersebut masih terdapat beberapa kesalahan pada saat pembuatan invoice dan packinglist, dan adanya keterlambatan pada saat pengiriman dokumen pengapalan. Hal ini disebabkan karena kurangnya Sumber Daya Manusia (SDM) yang ada di perusahaan sehingga ada yang merangkap dua perkerjaan sekaligus.

\section{Saran}

Dalam melakukan proses pembuatan dokumen Invoice dan packing list bagian eksportir harus lebih teliti supaya tidak terjadi kesalahan, dilakukan pengecekan terlebih dahulu dan pastikan ke costumer bahwa invoice yang dibuat telah sesuai dengan pesanan. Untuk dibagian ekspor seharusnya ada penambahan karyawan supaya tidak hanya satu orang yang menangani semua pekerjaan yang bisa mengakibatkan terjadi nya kesalahan dan keterlambatan dalam mengurus dan pengiriman dokumen. 


\section{DAFTAR PUSTAKA}

Amir, M. (2008). Export-Import Business. jakarta: Victory Jaya Abadi.

Mulyadi. (2016). Sistem Informasi Akuntansi. Jakarta: Salemba Empat.

Purwito, A. (2008). Kepabeanan dan Cukai Pajak lalu Lintas Barang Konsep. Jakarta: Badan Penerbit Fakultas Hukum Universitas Indonesia.

Retrieved from Official Website Direktorat Jendral Pajak. Diambil dari website: http://www.beacukai.go.id/arsip/pab lekspor.html (diakses tanggal 04 Juli 2019)

Sasono, H. B. (2013). Manajemen Ekspor dan Perdagangan Internasional. Yogyakarta: Percetakan Andi Offset.

Susilo, A. (2013). Panduan Pintar Ekspor Impor. Jakarta: TransMedia 